\title{
TADA2A wt Allele
}

National Cancer Institute

\section{Source}

National Cancer Institute. TADA2A wt Allele. NCI Thesaurus. Code C101470.

Human TADA2A wild-type allele is located within 17q12-q21 and is approximately $71 \mathrm{~kb}$ in length. This allele, which encodes transcriptional adapter 2 -alpha protein, is involved in the modulation of both histone modification and transcription. 